\title{
Komt een psycholoog bij de dokter
}

Citation for published version (APA):

Ponds, R. W. H. M. (2012). Komt een psycholoog bij de dokter. Maastricht University. https://doi.org/10.26481/spe.20121102rp

Document status and date:

Published: 02/11/2012

DOI:

10.26481/spe.20121102rp

Document Version:

Publisher's PDF, also known as Version of record

\section{Please check the document version of this publication:}

- A submitted manuscript is the version of the article upon submission and before peer-review. There can be important differences between the submitted version and the official published version of record.

People interested in the research are advised to contact the author for the final version of the publication, or visit the DOI to the publisher's website.

- The final author version and the galley proof are versions of the publication after peer review.

- The final published version features the final layout of the paper including the volume, issue and page numbers.

Link to publication

\footnotetext{
General rights rights.

- You may freely distribute the URL identifying the publication in the public portal. please follow below link for the End User Agreement:

www.umlib.nl/taverne-license

Take down policy

If you believe that this document breaches copyright please contact us at:

repository@maastrichtuniversity.nl

providing details and we will investigate your claim.
}

Copyright and moral rights for the publications made accessible in the public portal are retained by the authors and/or other copyright owners and it is a condition of accessing publications that users recognise and abide by the legal requirements associated with these

- Users may download and print one copy of any publication from the public portal for the purpose of private study or research.

- You may not further distribute the material or use it for any profit-making activity or commercial gain

If the publication is distributed under the terms of Article $25 \mathrm{fa}$ of the Dutch Copyright Act, indicated by the "Taverne" license above, 
Prof. dr. Rudolf W.H.M. Ponds

Faculty of Health, Medicine and Life Sciences

\section{Komt een psycholoog bij de dokter}




\section{KOMT EEN PSYCHOLOOG BIJ DE DOKTER}

Inaugurele rede uitgesproken ter aanvaarding van de bijzondere leerstoel Medisch Psychologie

Faculty of Health, Medicine and Life Sciences

Maastricht University

Maastricht, 2 november 2012

Prof. dr. Rudolf W.H.M. Ponds 
Mijnheer de Rector Magnificus, gewaardeerde collega's, familie en vrienden,

\section{Inleiding}

De titel van mijn oratie belooft niet veel goeds. Het parodieert op de titel van een van de meest gelezen maar ook verguisde boeken van de afgelopen jaren. Met de tweede hoofdpersoon in dat boek, de vrouw, loopt het niet goed af. Ze is ernstig ziek en gaat dood. In de medische zorg voor haar laat men de nodige steken vallen. De psycholoog in mijn verhaal overlijdt gelukkig niet. Wel is ziekte en de rol van de arts en psycholoog daarin een belangrijk thema. Mijn stelling daarbij is dat de psycholoog in de zorg zich te bescheiden opstelt. Collega Jan Derksen stelde vast dat psychologen, vergeleken met andere professionals, consistent laag scoren op zelfbeeld. Hij spreekt van een tekort aan narcisme, wat de daadkracht uiteraard niet ten goede komt.

In het eerste deel van mijn oratie zal ik stilstaan bij de opstelling van de psycholoog in de zorg. Binnen de zorg hebben arts en psycholoog hebben een gecompliceerde relatie. Dat is mede het gevolg van een aantal onhandigheden van de psycholoog. Ik vervolg mijn verhaal met de rol van de psycholoog in het somatische ziekenhuis en eindig bij mijn eigen afdeling en de daar te verwachten ontwikkelingen in zorg, onderwijs en onderzoek.

\section{De psycholoog in de zorg}

Het zal ergens in de jaren tachtig zijn geweest dat onze vertrouwde huisarts in het dorp zijn praktijk overdeed aan een jonge, net afgestudeerde arts. Mijn moeder bezocht hem voor al langer bestaande maagklachten. Na dit consult meldde ze ons lichtelijk verbaasd en mogelijk ook wat geïrriteerd, dat de jonge arts haar had gevraagd of ze ook last had van spanningen en of ze de drukte van het grote gezin en bedrijf wel aankon. lets wat we nu heel gewoon zouden vinden.

Deze huisarts had in zijn opleiding vast kennisgemaakt met een voorloper van wat we tegenwoordig het biopsychosociale model van gezondheid, ziekte en ziektegedrag noemen ${ }^{1}$. $U$ ziet het hier in zijn eenvoudigste vorm afgebeeld. 


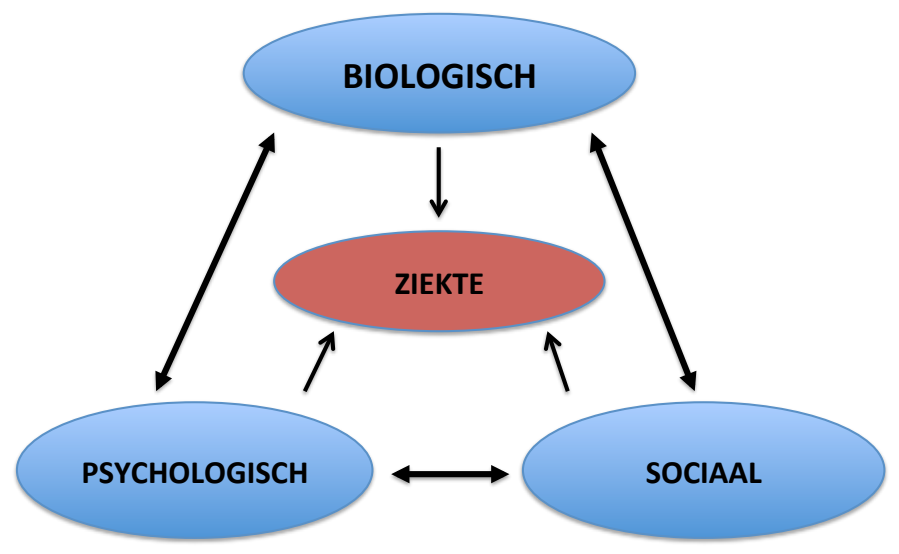

De essentie van het model is dat ziekte, niet alleen bepaald wordt door lichamelijke of biologische factoren, maar ook door psychologische factoren, zoals somberheid of piekeren en omgevingsfactoren, zoals een hoge werkdruk of een ongezonde leefstijl binnen het gezin. Alle medische opleidingen hebben dit model als basis voor de inrichting van hun artsenopleiding. Wanneer psychosociale aspecten sterk op de voorgrond staan, zal de arts een beroep doen op de psycholoog. De inbreng van de psycholoog is daarbij echter niet altijd duidelijk of overtuigend. Ter illustratie het volgende voorbeeld. Enige tijd geleden werd ik gevraagd om aan een groep verzekeringsartsen uitleg te geven over het psychodiagnostisch onderzoek. De voorzitter eindigde zijn introductie met het uitspreken van de wens dat "... men nu handvatten zou krijgen om het psychologisch rapport beter te kunnen begrijpen". Dat vond ik een vreemde opmerking, aannemende dat psychologische onderzoeken worden aangevraagd om ergens een helder antwoord op te krijgen. Ik hoor dergelijke opmerkingen echter vaak - het oordeel van de psycholoog over een patiënt is niet altijd duidelijk en de behandeling niet transparant. Ik neem, weer ter illustratie, een aantal bezwaren van artsen met u door.

(1) Allereerst de geslotenheid van het psychologisch dossier. Het dossier is volgens onze beroepscode ${ }^{2}$ en de Algemene Standaard Testgebruik ${ }^{3}$ alleen toegankelijk voor de patiënt en psycholoog. Het psychologisch rapport wordt uitsluitend verstrekt aan de opdrachtgever. In de praktijk is dit steeds minder werkbaar. Wie is bijvoorbeeld de opdrachtgever nu we bijna alleen nog maar werken in multidisciplinaire teams, waar het delen van informatie juist een kwaliteitskenmerk is. De psycholoog claimt hier vaak een uitzondering en houdt het dossier gesloten. Dat is niet praktisch en onnodig, aannemende dat de collega's in het multidisciplinaire team vanuit hun eigen beroepsethiek zorgvuldig zullen omgaan met psychologische gegevens. Er spreekt bovendien een ongewild wantrouwen uit. De geslotenheid is verder ook een 
vreemd signaal naar de arts. In de opleiding doen we alle moeite om de arts te laten inzien dat ziekte en ziektegedrag mede bepaald worden door psychosociale factoren. Vervolgens houden we deze informatie weg bij de praktiserende arts! Dat is weinig bevorderlijk voor het voeden van de psychologische blik bij de arts.

(2) Wachtlijsten voor psychologische onderzoeken kunnen lang zijn. Mede daardoor wordt terecht de vraag gesteld waarom die onderzoeken zo uitgebreid moeten zijn. Psychologen reageren daar vaak kribbig op, maar eerlijk gezegd kan het vaak met minder. Een psychodiagnostisch onderzoek start je immers niet blind. Op basis van het klinische interview en andere voorinformatie heb je een hypothese. Het test- en vragenlijstonderzoek is vervolgens een methode om deze hypothese te onderzoeken. Over hoeveel en welke tests en vragenlijsten daarbij nodig zijn is de Algemene Standaard Testgebruik duidelijk. Er moet beredeneerde spaarzaamheid worden betracht. Alleen wanneer een test of vragenlijst de kwaliteit van de uitspraak wezenlijk kan verbeteren is het gebruik gerechtvaardigd. Met dat criterium kunnen er beslist tests en vragenlijsten weg, zo is mijn eigen ervaring. Dat beperkt de belasting voor de patiënt, maar getuigt vooral van professionaliteit.

(3) Psychologen bedienen zich verder graag van woorden en frasen als zou kunnen, misschien, mogelijk, niet uit te sluiten is en lijken. Enkelen van u kennen mijn stokpaardje: de psycholoog die rapporteert dat de patiënt 'gespannen lijkt' bij het testonderzoek. Wat moet je daar nu mee als aanvrager - had de psycholoog dat niet even kunnen vragen aan de patiënt? Het is ten slotte een belangrijke observatie. Echt bezwaarlijk wordt het als de psycholoog ook nog rapporteert dat 'de mogelijke gespannenheid de testresultaten nadelig kan hebben beïnvloed'. Als dan ook nog bij de diagnose een voorbehoud wordt gemaakt in de trant van 'er is mogelijk sprake van $\mathrm{x}$, maar $\mathrm{y}$ is niet uitgesloten' - terwijl dat nu juist de vraag was - dan is de arts terecht teleurgesteld. Let wel, het is goed mogelijk dat de onderzoeksgegevens geen eenduidige conclusie toelaten, maar beargumenteer en rapporteer dat dan en trek verder géén conclusie in plaats van twee halve.

(4) Psychologen hanteren in hun conclusies vaak onnodig vakjargon zoals 'gestuwde gevoelens', 'gelaagdheid van de persoon', 'verborgen tendenties', 'Sociale Inadequatie', 'performaal IQ', 'zwakke consolidatie' of 'vertraagde conceptshifting'. De aanvrager begrijpt dit zelden, laat staan de patiënt om wie het allemaal te doen is. En het kan met gemak simpeler. Als voorbeeld de volgende passage uit een rapport: ... in zijn gedrag speelt een sterke, waarschijnlijke neurotisch bepaalde, behoefte aan vrijheid een rol. Vermoedelijk legt de onbewust geïnternaliseerde dwang van een tirannieke vader hem nog steeds lam en doet dit angst in hem leven zodra hij iets moet etc, etc... Hier staat in meer alledaagse bewoordingen het volgende: ... patiënt geeft aan een grote behoefte te hebben aan vrijheid. Het zoeken 
naar vrijheid heeft een dwangmatig karakter. Hij heeft grote problemen zich te binden en verplichtingen na te komen. Mogelijkerwijs is dit te zien als een verlaat verzet tegen zijn vader die op onplezierige wijze verplichtingen bij de patiënt probeerde af te dwingen.... (voorbeeld ontleend aan Kooreman ${ }^{4}$ ). In het verlengde van de conclusie volgt het zo belangrijke advies. Ook hier is onduidelijkheid maar al te vaak troef: het advies ontbreekt, is weinigzeggend of laat alle mogelijkheden open. Juist bij het advies moeten belangrijke vragen worden beantwoord, zoals wel of niet een opname, de vraag of school of werk kan worden vervolgd en of inzichtgevende therapie haalbaar is. Dit is de plek waar de psycholoog zijn kwaliteiten kan en moet etaleren. Voor aarzeling is hier geen plaats.

\section{Heasitaritis psychologicus}

Het weifelen van de psycholoog is zo algemeen dat het wel haast een aandoening genoemd kan worden: heasitaritis psychologicus. Waar komt deze aandoening vandaan?

In de diagnostiek heeft het zeker te maken met de afstandelijke wijze waarop de patiënt wordt benaderd. Als een object dat doorgrond moet worden in plaats van een belanghebbende die, net als de psycholoog, graag wil weten waar zijn stemmingsschommelingen, zijn allesdoordringende onzekerheid of zijn vergeetachtigheid vandaan komen. Collega Kamphuis ziet in navolging van Finn een beter alternatief: de diagnostische therapeutische alliantie, waarbinnen psycholoog en patiënt gezamenlijk de diagnostische vragen formuleren en eveneens gezamenlijk de resultaten uitwerken ${ }^{5}$. Een aanpak die terecht aan populariteit wint. In de consensus tussen patiënt en psycholoog is voor aarzeling geen plaats meer. De psycholoog wordt een 'mededeelzame detective', zoals collega Henk van de Molen al in 1994 voorstond ${ }^{6}$.

Is de aarzeling mogelijk ook een hardnekkige nawee van de universitaire studie psychologie? 'Twijfel aan alles - gedrag kent vele verklaringen' wordt ons met de paplepel ingegoten, ook in de postdoctorale opleidingen. Deze twijfel is een goede basis voor ons vak: het houdt ons scherp en maakt ons tot goede onderzoekers. Het is vertaald in het ambitieuze 'scientist-practitioner' model van de praktiserende psycholoog: een zorgprofessional met een wetenschappelijke attitude, die zich naast praktijk- en ervaringskennis, ook baseert op de wetenschappelijke kennis en ontwikkelingen op zijn vakgebied ${ }^{7}$.

Het science-practitioner model is een mooi model; praktijk en wetenschap blijven elkaar voeden en de psycholoog blijft kritisch kijken naar zijn onderzoeks- en 
behandelmethoden. Maar op het individuele niveau van de patiënt ligt dit beslist anders - de patiënt is hier niet gebaat bij herhaalde academische twijfel - die wil een eenduidig antwoord en geholpen worden. Wordt dergelijke 'klinische daadkracht' wel voldoende onderwezen. Ik heb de indruk van niet. Zo is er in de postdoctorale beroepsopleidingen veel aandacht voor de beroepsethiek en het tuchtrecht, maar als dit niet gecombineerd wordt met een scholing in slagvaardig optreden bij de individuele patiënt, dan zal de toch al zo potente aarzeling van de psycholoog alleen maar worden versterkt.

Voor de zorg is de heasitaritis psychologicus niet zonder gevolgen. Ik wil dat aan de hand van eenvoudig figuur duidelijk maken.

zorgvragen: wie doet wat

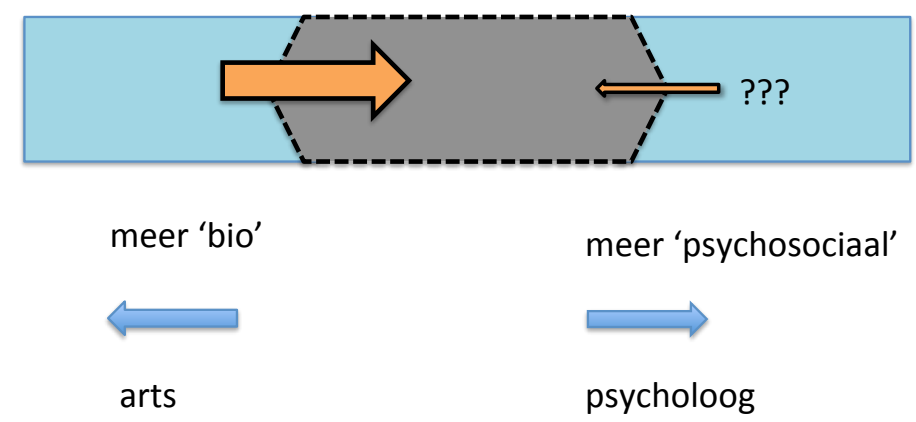

Bij een aanzienlijk aantal aandoeningen en klachten spelen zowel biologische als psychosociale aspecten een rol, in het plaatje het grijze gebied. Links daarvan liggen de eenduidige 'bio-ziektes' waar de arts direct kan handelen, rechts daarvan aandoeningen die vooral een psychosociale causaliteit hebben, denk bijvoorbeeld aan een burnout. Bij de 'gemengde aandoeningen' in het grijze gebied is de vraag relevant wie wat doet en wie de regie neemt. De arts verwijst hier deze patiënt graag naar de psycholoog: deze blijft echter onduidelijk in zijn diagnostiek en aarzelt om te gaan behandelen. Zijn bijdrage is gering. De arts wil en moet echter verder met zijn patiënt, hij moet handelen - zo wordt dat ook van hem verwacht. Hij zal meer medische verrichtingen inzetten- nog een pil, nog een opname of nog meer fysiotherapie. De psychosociale aspecten blijven onderbelicht en de kennis en kunde die de psycholoog hier had kunnen en moeten inzetten blijven achterwege. 
In de zorg zal de psycholoog kordater moeten optreden. Hij moet, daar waar passend, nadrukkelijk de regie nemen. De wet Beroepen Individuele Gezondheidszorg geeft hiertoe ook veel ruimte. Vaak wordt gedacht dat dit een wet is waarmee vooral beroepen en deskundigheden worden áfgebakend. Maar het is juist een wet die veel ruimte biedt: de zorgprofessional bepaalt zelf waarin hij bekwaam is en onderhoudt deze bekwaamheid. Aantoonbare bekwaamheid betekent vervolgens ook bevoegdheid. Nu zal iedereen natuurlijk primair opereren op zijn eigen deskundigheidsgebied, dat is ook wel verstandig en praktisch, maar er is veel speelruimte om behandelverantwoordelijkheid in de medische setting naar de psycholoog te schuiven als de bekwaamheid aanwezig is. Ook de arts mag zich, mits bekwaam, bewegen in het deskundigheidsgebied van de psycholoog - ik zie daar geen bezwaren. Evenzeer ligt het dan voor de hand de psycholoog de regie te geven op afdelingen, waar gedragsproblemen en cognitieve stoornissen op de voorgrond staan - het deskundigheidsgebied bij uitstek van de psycholoog. Denk bijvoorbeeld aan psychogeriatrie-afdelingen in verpleeghuizen of hersenletselafdelingen in revalidatiecentra.

Minder aarzelen, meer vertrouwen in eigen kunnen, en meer daadkracht is dan echter wel een vereiste. Het narcistisch tekort moet nadrukkelijk worden aangevuld.

\section{Naar het ziekenhuis}

Ik wil mij toespitsen op het werkveld van de medische psychologie. De medische psychologie richt zich op mensen die om verschillende redenen ziek zijn of zich ziek voelen en die in een medische omgeving zoals een ziekenhuis, revalidatiekliniek of verpleegkliniek worden behandeld en verzorgd ${ }^{8}$. Veel patiënten met lichamelijke klachten hebben ook emotionele problemen of problemen in hun gedrag. Deze problemen kunnen oorzaak zijn van de lichamelijke klachten of deze versterken. Dit geldt bijvoorbeeld voor hoofdpijnklachten of door spanning veroorzaakte hartklachten. Maar ook cognitieve klachten zoals vergeetachtigheid of concentratiezwakte hoeven niet direct te wijzen op hersenstoornissen, maar kunnen ook het gevolg zijn van vermoeidheid, pijn, depressie of angst voor dementie. 


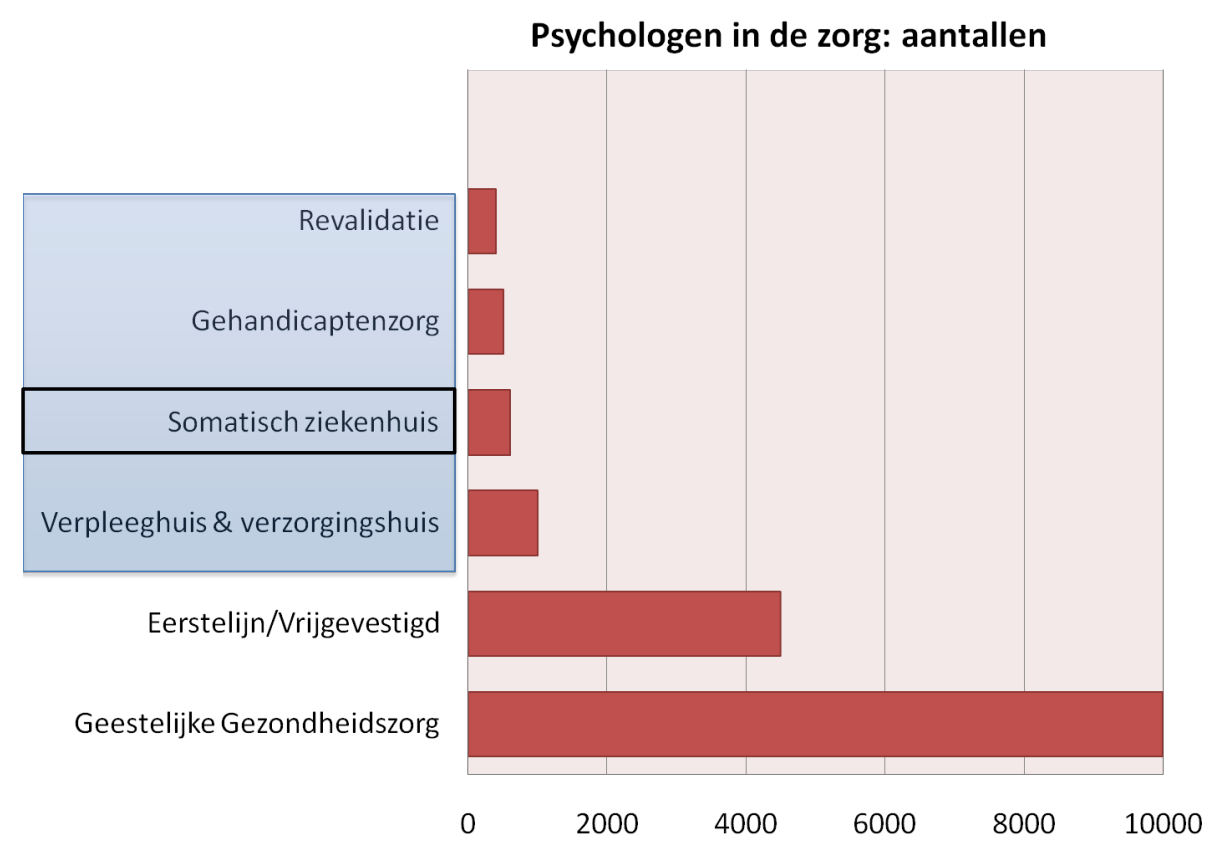

Er zijn naar schatting 17.000 psychologen werkzaam in de zorg, waarvan ruim de helft, ongeveer 10.000 in de geestelijke gezondheidszorg. Het aantal psychologen werkzaam binnen een medische setting is ongeveer 2500. Slechts 600 daarvan werken in algemene en academische ziekenhuizen, ofwel $3 \%$ van alle psychologen in de zorg. Hier verricht hij psychodiagnostiek waarmee persoonlijkheid, psychisch lijden en cognitieve schade in kaart wordt gebracht. Ook worden kortdurende psychologische behandelingen aangeboden. Dat loopt uiteen van crisisinterventie, psycho-educatie, kortdurende psychotherapie of neuropsychologische behandelingen.

In het ziekenhuis ziet de psycholoog grofweg twee groepen patiënten ${ }^{9}$. De eerste en grootste groep bestaat uit patiënten met chronische ziekten zoals kanker, hartfalen, longaandoeningen, diabetes, reuma of overgewicht. Ook dementie of hersenletsel met blijvende restverschijnselen kunnen als een chronische aandoening worden beschouwd. Chronische ziekten hebben een grote invloed op het dagelijks functioneren en vragen voortdurend om aanpassingen bij zowel patiënt als zijn omgeving. Men moet leven met een onzekere prognose en maar al te vaak zijn er complicaties die medische ingrepen nodig maken. Dit alles kan leiden tot ernstige psychische problemen.

De tweede groep betreft patiënten met wat in het medisch jargon wordt genoemd 'functionele' of somatoforme klachten: lichamelijke of cognitieve klachten waarvoor geen medische verklaring kan worden gevonden, zoals pijn, vermoeidheid, duizeligheid, slapeloosheid, concentratieverlies en geheugenzwakte. Artsen, maar 
ook wel psychologen, spreken dan al snel van 'vage' klachten. Dit wil niet zeggen dat de klachten vaag zijn- patiënten kunnen de klacht prima verwoorden en aanwijzen maar wel dat de interpretatie moeilijk is, ook al wordt vaak een psychische oorzaak vermoed. De cijfers over het vóórkomen van deze functionele lichamelijke klachten liegen er niet om. Tussen de 10 tot $50 \%$ van de Nederlanders heeft ergens in zijn leven serieuze hinder van dergelijke klachten. De meeste van deze klachten verdwijnen vanzelf. Toch wordt een substantieel deel van de mensen met dergelijke klachten wordt uiteindelijk ook verwezen naar het ziekenhuis.

Gegeven het grote aantal chronisch-zieke patiënten en de grote groep patiënten met functionele klachten, zult $\mathrm{u}$ denken dat de psycholoog veel patiënten ziet in het ziekenhuis. Maar dit is eigenlijk niet zo. Collega Soons heeft eens berekend dat de medisch psycholoog betrokken is bij $0.4 \%$ van alle patiënten die behandeld worden in een ziekenhuis ${ }^{9}$. Dat is slechts één op de 250 patiënten ${ }^{9}$. Een opmerkelijk laag getal, dat de nodige vragen oproept: is de arts blind voor psychische klachten bij zijn patiënten, verzuimt hij door te verwijzen, of weet hij zelf de juiste aanpak te kiezen en is de psycholoog niet nodig. Dat is nog eens interessant om nader te onderzoeken, vooral ook omdat bekend is dat de interventies van de medische psycholoog de kwaliteit van het medisch handelen en daarmee de kwaliteit van leven voor de patiënt aanzienlijk kan verbeteren. Dat kan ook kostenbesparend werken, omdat het herstel wordt versneld en bijvoorbeeld de ligtijd wordt verkort.

\section{Somatoforme en cogniforme stoornissen}

Ik kom terug op de al genoemde functionele of somatoforme klachten. Tot voor kort spraken we ook wel van psychosomatische klachten, een term die de meeste van u wel kennen. Tegenwoordig wordt de meer neutrale term SOLK, ofwel somatisch onvoldoende verklaarde klachten, gebruikt. Binnen ons ziekenhuis is een bijzondere klinische en poliklinische voorziening voor patiënten met dergelijke klachten, de zogeheten MedPsychUnit (MPU). Hier vindt specifieke diagnostiek en behandeling plaats vanuit verschillende disciplines, waaronder die van de psycholoog en psychiater. De nadruk ligt tot nu toe op onbegrepen lichamelijke klachten, maar er liggen alle mogelijkheden om dit uit te breiden naar onbegrepen of onverklaarde cognitieve klachten. Het gaat dan om patiënten die zeer beperkende cognitieve problemen ervaren zoals ernstig geheugenverlies, extreme concentratiezwakte of mentale vermoeidheid, waarvoor geen afdoende medische verklaring wordt gevonden. Op de geheugenpolikliniek treffen we deze patiënten regelmatig aan. Zo beschreven Verhey en ikzelf al in 1991 een patiënt die extreem dwangmatig bezig was met zijn vergeten ${ }^{10}$. Hij ging alle situaties uit de weg, waarbij hij verwachtte dat er een expliciet beroep werd gedaan op zijn geheugen. Ook ging hij liever niet de 
straat op omdat hij mogelijk reclames zou zien op passerende bussen of vrachtauto's, die hij dan weer moest onthouden. Enkele jaren geleden onderzochten we een man met een volledig verlies van geheugen na een minimaal herseninfarct ${ }^{11}$. Hij wist niets meer van zijn eigen leven en hij was basale vaardigheden kwijt zoals koken, het gebruik van gereedschap, of het bedienen van eenvoudige huishoudelijke apparaten. Hij kon niet meer lezen, schrijven of rekenen en van geld begreep hij niets meer. Zijn geheugen voor recente zaken bedroeg exact twee dagen: alles wat zich langer dan twee dagen geleden had voorgedaan was volledig gewist. Zo werden zijn eigen uitwonende dochters vreemden voor hem als hij ze langer dan twee dagen niet had gezien. Ook als $u$ geen verstand hebt van geheugenstoornissen, zal $u$ dit toch wel bizar voorkomen. Bekend is ook het extreme klachtenpatroon dat mensen kunnen ontwikkelen na een hersenschudding of whiplash - niet alleen pijnklachten, maar ook vergaande cognitieve uitval. Verder zien we frequent patiënten met extreme angst voor dementie, die daardoor, ironisch genoeg, een volmaakt geheugen voor vergeetmomenten ontwikkelen. Alledaagse en onschuldige vergeetmomenten worden geduid als voortekenen van dementie, die de angst verder laat toenemen en het gevoel van geheugenfalen versterkt.

Naar analogie van de somatoforme stoornissen, wordt sinds kort de term 'cogniforme stoornissen' gebruikt om deze onbegrepen cognitieve klachten te typeren $^{12}$. In de komende jaren willen we hier verder onderzoek naar doen - hoe ontstaan deze ernstig invaliderende klachten en hoe kunnen ze het beste worden behandeld.

Functionele klachten zijn vaak hardnekkig. In de lange zoektocht naar erkenning kunnen patiënten hun klachten uitgebreid en gedetailleerd etaleren, soms op het theatrale af. Artsen ervaren deze patiënten al snel als lastig en claimend en verwijzen daarom graag door naar de psycholoog. Toch blijft juist de arts hier soms te lang twijfelen, bijvoorbeeld door de angst een medische misser te maken. Het blijkt namelijk dat bij ongeveer 10 tot $20 \%$ van de patiënten met functionele klachten na verloop van tijd alsnog een medische oorzaak gevonden wordt. Verwijzing naar weer een medische specialist is dan verleidelijk, al is de kans op een oplossing minimaal. Een verwijzing naar de psycholoog of psychiater is verder ook niet gemakkelijk te verkopen. De arts moet een voor de patiënt aanvaardbare uitleg geven over psychologisch factoren die ten grondslag liggen aan zijn klachten. En dit bij een patiënt die niet direct inziet waarom bij een voor hem evident lichamelijk of cognitief probleem, zijn persoon onder de loep moet worden genomen. Deze uitleg is in de praktijk van de spreekkamer bijzonder moeilijk; welke woorden of welke metaforen kun je hier gebruiken, hoe voorkom je een eindeloze 'ja-maar' discussie met de patiënt die altijd wel een symptoom of voorval weet dat net niet bij de uitleg past. Op dit hele praktische niveau van uitleg gaat het vaak mis. In het slechtste 
geval verwijst de arts dan maar zonder al te veel toelichting - het gevreesde 'nothing wrong' scenario: "ik kan niets bij $u$ vinden, en daarom stuur ik $u$ door naar de psycholoog". Het is echter bij uitstek aan de arts om de medische verklaring die de patiënt verwacht, om te zetten in een even plausibele en ernstig te nemen psychologische verklaring. Deze stap is allesbepalend voor het succes van de psychologische behandeling die moet volgen. Een psychologische behandeling die nadrukkelijk ook binnen het medische circuit moet plaatsvinden - de psycholoog zit wat mij betreft letterlijk tussen of naast de arts om de vloeiende overgang van 'bio' naar 'psycho' uit het biopsychosociale model te benadrukken. Mede daarom ben ik geen voorstander dergelijke zorg buiten het ziekenhuis te plaatsen, zoals we dat bijvoorbeeld zien in de GGZ, waar aparte zorgprogramma's voor somatoforme stoornissen worden opgezet.

\section{Medische psychologie en neuropsychologie}

Mijn benoeming tot hoogleraar Medische Psychologie is gegeven mijn eigen specialisme, klinisch neuropsycholoog, bijzonder. Mijn eerste deskundigheid betreft patiënten met hersenaandoeningen, niet patiënten met lichamelijke aandoeningen. In onze landelijke beroepsvereniging van psychologen, het NIP, bestaan aparte secties voor medische psychologen en voor neuropsychologen. Binnen het Convent van Hoogleraren Medische Psychologie ben ik verder de enige klinisch neuropsycholoog.

Deze scheiding tussen medische psychologie en neuropsychologie heeft haar achtergrond. Traditioneel is het psychotherapeutisch denken en handelen dominant in de medische psychologie - de meeste medisch psychologen zijn ook geschoold in deze richting. Neuropsychologische expertise is wel aanwezig op een afdeling Medische psychologie, maar vormt niet de hoofdmoot. In de afgelopen 20 jaar is de belangstelling voor neuropsychologie echter enorm toegenomen. We zijn, ook als leek, mateloos geïnteresseerd geraakt in de relatie tussen hersenen en normaal en abnormaal gedrag. De belangstelling voor hersenonderzoek is ongekend en de waardering zelfs wat buiten proportie. De verwachting dat we door de vergaande inkijk in de hersenen binnenkort alles kunnen verklaren en behandelen zal voorlopig nog niet worden ingelost. De enorme neuro-belangstelling heeft er wel toe geleid dat het aantal neuropsychologen in de zorg in de laatste decennia sterk is toegenomen. Dit is een goede ontwikkeling. De neuropsycholoog is bij uitstek in staat om de vele gevolgen van hersenletsel in kaart te brengen en daarmee ook de grenzen en mogelijkheden van veranderbaarheid en leerbaarheid bij de patiënt. Dat doen we overigens nog steeds gewoon aan het bureau, met tests en vragenlijsten en een goed gesprek. De mooie hersenplaatjes die we tegenwoordig kunnen maken 
dragen nog niet wezenlijk bij aan de inventarisatie van de dagelijkse gevolgen van hersenletsel of aan de inhoud van neuropsychologische behandelingen.

Vanwege de groei van het aantal neuropsychologen in de zorg, werd in 1998 een eigen beroepssectie opgericht. In zeer korte tijd werd de sectie Neuropsychologie de op een na grootste binnen de sector Gezondheidszorg. Ook lukte het, na een lang en taai traject, een eigen specialisme 'klinisch neuropsycholoog' erkend te krijgen, de tweede naast het specialisme van de klinisch psycholoog. Een deel van de medisch psychologen had hier liever de specialist 'medisch psycholoog' gezien, die dan ook geschoold zou zijn in de neuropsychologie. Dat wilden wij beslist niet - het kennisgebied van de neuropsychologie was en is daarvoor te groot en te specialistisch. Mede door deze discussie stonden we een tijd lang met de ruggen naar elkaar.

Er zijn echter verschillende ontwikkelingen die maken dat de medisch psycholoog en de neuropsycholoog meer zullen en moeten gaan samenwerken. Twee wil ik er hier noemen. Bij veel primair lichamelijke aandoeningen als diabetes, hartfalen of chronische obstructieve longziekten, wordt duidelijker dat het primair lichamelijke ziekteproces uiteindelijk ook tot hersenbeschadiging kan leiden met bijbehorende cognitieve en emotionele problemen. Dit nieuwe kennisgebied wordt omschreven als 'medical neuropsychology', in het Nederlands te vertalen met 'somatische neuropsychologie' ${ }^{13}$. Deze ontwikkeling dwingt de medisch psycholoog om zich meer neuropsychologisch te scholen en omgekeerd.

Een tweede en zeer belangrijke reden voor verdergaande samenwerking is de kennis van de medische psychologie op het gebied van psychotherapie binnen de medische setting. Bij dementie en hersenletsel is er vaak sprake van ernstige psychische problematiek. Hoewel de neuropsycholoog beslist goed is in het behandelen van cognitieve problemen, is hij in de behandeling van psychische klachten nog wat linkshandig. Toch liggen vooral hier de vragen van patiënten en familie. Emotioneleen gedragsproblemen komen vaak voor na hersenaandoeningen. Ze ontstaan vaak geleidelijk en zijn vooral manifest in de latere fase na het hersenletsel. In de volgende grafiek wordt dat duidelijk. 


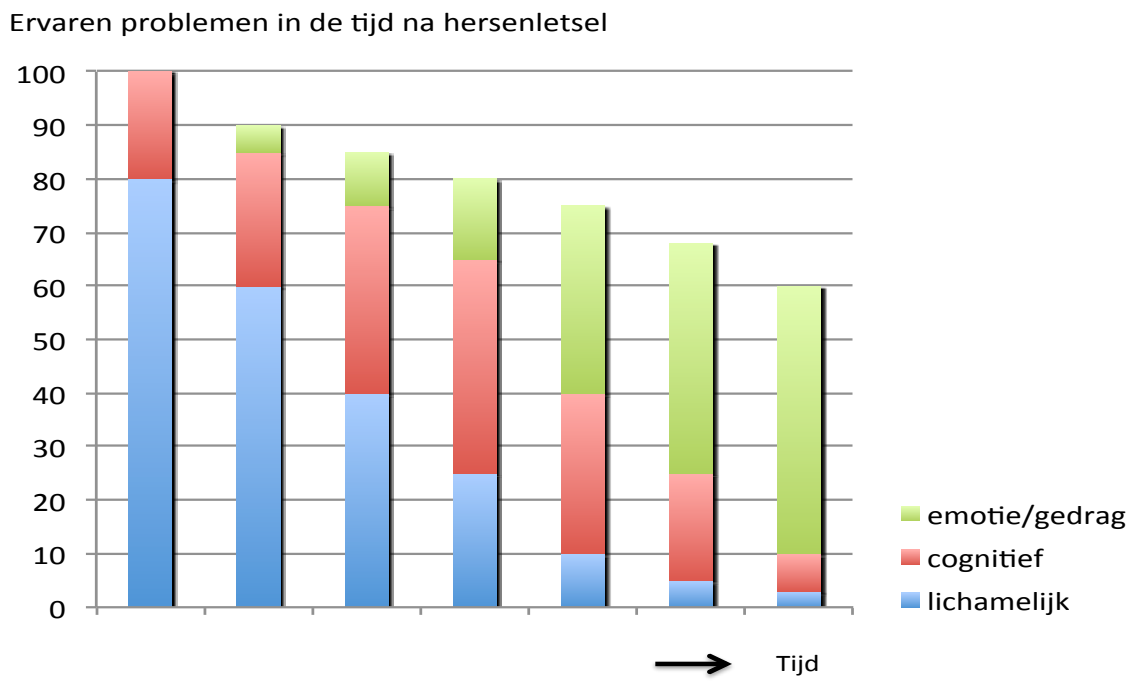

$\mathrm{U}$ ziet dat in de eerste periode na hersenletsel vooral de lichamelijke en cognitieve problemen op de voorgrond staan, pas na verloop van tijd worden de emotioneleen gedragsproblemen zichtbaar zoals prikkelbaarheid, apathie, ontremd gedrag of emotionele vervlakking. Juist deze veranderingen zijn een enorme belasting voor de patiënt, familie en omgeving. Dergelijke problemen komen vooral aan het licht als de patiënt is uitbehandeld en weer thuis is. Om hier passende behandeling te bieden moeten wij gebruik maken van het brede behandelaanbod dat de medisch psychologen in huis hebben. Denk aan de methoden uit de klassieke gedragstherapie zoals exposure, de cognitief-gedragstherapie gericht op het bijsturen van ziektebevorderende gedachten, directieve en oplossingsgerichte therapie gericht op het uitvergroten van het gezonde gedrag, gezins- en relatietherapie en, de nieuwe loten aan de therapieboom, mindfulness en acceptance commitment therapie waarbij patiënten wordt geleerd op constructieve wijze te berusten in de onomkeerbare beperkingen en handicaps.

$\mathrm{Nu}$ hebben wij als neuropsychologen hier nog een hele agenda voor de boeg. Het is geen kwestie van 'copy-paste' om deze therapeutische behandelingen geschikt te maken voor patiënten met hersenletsel. De beschadigde hersenen die leiden tot problemen, moeten immers ook worden aangesproken om diezelfde problemen op te lossen. Het leren verloopt wezenlijk anders dan in niet-beschadigde hersenen. Zo is bijvoorbeeld het ziektebesef en - inzicht vaak verstoord, waardoor de behandelmotivatie gering kan zijn of zelfs geheel ontbreekt. Of de frustratietolerantie is zo laag, dat geen enkele teleurstelling - onvermijdelijk bij het oefenen van nieuw gedrag - wordt verdragen. Een egocentrische focus, frequent na hersenletsel, kan betekenen dat de patiënt alleen maar de omgeving als probleem ziet en zelf beslist niet wil veranderen. Patiënten missen soms het vermogen om 
over zichzelf en hun gedrag te reflecteren - een belangrijke voorwaarde om verandering van gedrag mogelijk te maken. Vaak is er sprake van beperkte mentale belastbaarheid, een zwak geheugen of slechte concentratie waardoor het leren ernstig wordt beperkt en dat wat eenmaal geleerd weer snel wordt vergeten.

Dergelijke complicaties maken het omzetten en aanpassen van psychotherapeutische behandelmethoden naar patiënten met hersenletsel tot een ingewikkelde klus. Het vereist uitgebreide kennis over de aard en complexiteit van de gevolgen van hersenletsel. Kennis die besloten is in het specialisme van de klinisch neuropsycholoog. De aangepaste psychotherapie voor hersenletselpatiënten wordt in ons vak samengevat onder het koepelbegrip 'neuropsychotherapie'. Geen mooie term, maar het dekt voorlopig de lading.

\section{De afdeling Medische Psychologie}

Ik neem $\mathrm{u}$ tot slot graag mee naar mijn afdeling Medische Psychologie en de ontwikkelingen die ik voorzie in zorg, onderwijs en onderzoek.

Zorg

In de komende jaren zal het academisch ziekenhuis zijn rol als algemeen streekziekenhuis verkleinen en de academische zorg-, onderwijs- en onderzoekstaken vergroten. De zorg zal steeds specialistischer worden, waarbij de reguliere zorg meer bij ziekenhuizen in de regio komt te liggen. Medewerkers van de afdeling Medische Psychologie zullen zich straks meer academisch moeten profileren en daar ook op worden beoordeeld. Die profilering kan op verschillende gebieden: zorgontwikkeling, wetenschappelijk onderzoek of onderwijs aan artsen en psychologen.

De verdergaande academisering maakt samenwerking met externe zorgpartners nog belangrijker dan het nu al is. Onze afdeling zal meer focussen op complexe diagnostiek en indicatiestelling voor behandelingen. Behandelingen zullen vooral specialistisch zijn en vaker onderdeel vormen van een onderzoeks- of ontwikkelproject. Minder specialistische behandelingen zullen in samenwerking met of door externe partners worden uitgevoerd. Daar hebben we tot nu toe goede ervaringen mee. Voorbeelden zijn de psychologische begeleiding van demente patiënten en hun partners door de RIAGG Ouderenzorg, psychologische begeleiding van patiënten van de MedPsychUnit door de eerstelijnspraktijk Prima en het bundelen van de seksuologische hulpverlening in de regio binnen één centrum Seksuologie. Samenwerking vraagt wel om een complementaire in plaats van concurrerende opstelling tussen de instellingen. Dat is niet vanzelfsprekend in de 
zorg, waar het primaat van het geld instellingen maar al te vaak tot egocentrisch handelen dwingt, waardoor ketenzorg moeilijk van de grond komt of moeilijk kan worden behouden.

\section{Onderwijs}

Medewerkers van de afdeling leveren een flinke bijdrage in het geneeskundeonderwijs. Over deze tijdrovende onderwijslast wordt nogal gezucht, omdat het op gespannen voet staat met de al even tijdrovende zorgtaken. Toch zou dit niet moeten. Alleen via het onderwijs kunnen we de arts die medisch-psychologische kennis bijbrengen die wij zo noodzakelijk achten. Medisch-psychologische en neuropsychologische onderwerpen zijn minder aanwezig in het huidige curriculum dan in de beginjaren, zo hoor ik herhaaldelijk. Het spreekt voor zich dat ik deze onderwerpen graag weer zou willen terugbrengen, ook al betekent het nog meer onderwijstaken voor onze afdeling dan nu. De plus van MUMC+ staat daar immers niet voor niets - het symboliseert de brede biopsychosociale visie op gezondheid die het Maastricht Universitair Medisch Centrum uitdraagt.

Psychologen van de afdeling leveren tevens een bijdrage aan het onderwijs binnen de Faculteit Psychologie en Neurowetenschappen, overwegend binnen het masteronderwijs. Nu de faculteit Psychologie zich ook meer richt op de student die straks in de zorg wil werken, is het denkbaar dat onze inzet in het psychologie onderwijs verder gaat toenemen. Dat zou ook prima zijn - onze klinisch-wetenschappelijke inbreng voedt immers het gewenste 'scientist-practitioner' model.

Veel van onze medewerkers leveren ook een bijdrage aan de postdoctorale opleiding tot gezondheidszorgpsycholoog en de specialist-psycholoog. Dit kan zijn als docent of werkbegeleider en supervisor bij onze praktijkopleidingsplekken. Deze opleidingsplekken willen we een meer academische signatuur geven - dat betekent bijvoorbeeld dat promovendi van de eigen onderzoeksschool voorrang krijgen bij de invulling. Ook zouden we de opleiding graag combineren met een promotietraject. Binnen de postdoctorale opleiding ga ik zeker ook pleiten voor een onderwijsmodule 'klinische daadkracht voor psychologen'. Ik zeg het wat schertsend, maar meen het serieus.

\section{Onderzoek}

Medewerkers van de afdeling participeren in diverse wetenschappelijke onderzoeksprojecten of zijn zelf kartrekker van een onderzoeksthema. Voorbeelden zijn behandeling van anorexia nervosa en morbide obesitas, cognitieve en 
emotionele stoornissen bij Parkinson, somatoforme stoornissen en specifieke thema's uit de seksuologie.

De neuropsychologen van de afdeling zijn vooral betrokken bij het onderzoek naar veroudering en dementie dat is ondergebracht bij het Alzheimer Centrum Limburg. Binnen dit centrum werken onderzoekers en clinici samen om antwoorden te vinden op de vraag hoe dementie ontstaat, hoe dementie zo vroeg mogelijk kan worden gediagnosticeerd en wat de behandelmogelijkheden zijn. Een aantal thema's heeft daarbij mijn bijzondere aandacht.

Allereerst de psychologische gevolgen van vroegdiagnostiek. Binnen de geheugenpolikliniek beoordelen wij op het scherpst van de snede: net wel/net geen dementie. Daarbij treffen we ook een grote groep patiënten aan die geen dementie heeft, maar wel lichte geheugenstoornissen. Hiervoor gebruiken we de term 'mild cognitive impairment' of $\mathrm{MCl}$. Patiënten met $\mathrm{MCl}$ hebben een aanmerkelijk verhoogd risico op het ontwikkelen van dementie. Ons diagnostische oordeel is in hoofdzaak gebaseerd op het klinisch interview, een hersenfoto en vooral de uitkomsten van het neuropsychologisch onderzoek. Tegenwoordig zijn daar de zogeheten 'biomarkers' bijgekomen. Biomarkers zijn bijvoorbeeld dementiespecifieke afwijkingen in hersenvocht verkregen met een ruggenprik. Of zeer specifieke hersenafwijkingen op speciale hersenscans. Op basis van de biomarkers kan het onderliggend ziekteproces van dementie al worden aangetoond, terwijl er nog geen klinische symptomen van dementie zijn. De patiënt is bijvoorbeeld wel vergeetachtig, maar weet zich verder nog prima te redden. Er woedt momenteel een heftige discussie over de betrouwbaarheid van deze biomarkers als voorspellers van latere dementie. De meeste clinici nemen deze biomarkers daarom niet mee in het klinische oordeel. Ze worden wel gemeten, maar uitsluitend voor wetenschappelijke doeleinden. Maar dit gaat naar mijn inschatting snel veranderen. Ten eerste zal de betrouwbaarheid van de biomarkers toenemen. Ten tweede verwacht ik dat de steeds beter geïnformeerde en mondige oudere patiënt van nu ons daar expliciet naar gaat vragen. Daarmee ontstaat een steeds grotere groep patiënten die nog geen dementie heeft, maar waarbij het wel heel aannemelijk is dat dat enkele jaren later wel zo is. Meer nog dan nu, zal behandeling en begeleiding na de diagnostiek nodig zijn voor de vele vragen, twijfels en angsten die inherent zijn aan vroegdiagnostiek. De psychologische behandelprotocollen die wij hierbij al gebruiken, willen we verder ontwikkelen en evalueren.

Het klinisch oordeel zal altijd een cruciaal onderdeel blijven in de vroegdiagnostiek van dementie. $U$ zult denken dat vergeetachtigheid het eerste symptoom is van dementie, maar het lijkt dat subtiele gedragsveranderingen zoals enig interesseverlies, vermoeidheid, prikkelbaarheid en emotionele labiliteit mogelijk nog 
eerdere manifestaties zijn van wat later dementie blijkt. We typeren dit als het 'emotionele kwetsbaarheidssyndroom'. Collega Verhey sprak in zijn oratie uit 2002 al de wens uit om dit fenomeen beter te gaan meten ${ }^{14}$. Dat is ons nu 10 jaar later nog steeds niet gelukt. Deze subtiele gedragsveranderingen blijken moeilijk te vangen in vragenlijsten of het klinische interview. Met de groep van Inez Germeys, willen we onderzoeken in hoeverre PsyMate, hiervoor wel een geschikt instrument is. Met de PsyMate is het mogelijk directe ervaringen en gedrag te meten in de dagelijkse context ${ }^{15}$. Daarmee wordt een klinische fijnmazigheid bereikt, die we niet kunnen terugvinden in een interview of vragenlijst.

We willen ons ook richten op de effecten van cognitieve functietrainingen bij veroudering, $\mathrm{MCl}$ en lichte dementie. Wij kijken dan naar de meer serieuze vorm van wat $U$ overal op internet kunt aantreffen onder de brede noemer van 'train your brain' of hersengymnastiek. Meestal een compilatie van cognitieve taakjes die betrekking hebben op het geheugen, op aandacht, op snelheid van reageren of rekenvaardigheden, waarbij de moeilijkheidsgraad afhankelijk van het trainingsresultaat steeds omhoog gaat. Een vorm van mentale conditietraining, waarbij je hersens of geheugen worden getraind naar analogie van spiertraining. Daarvan hebben neuropsychologen, waaronder ikzelf, altijd geroepen dat het niet werkt omdat het geheugen niet werkt als een spier - een algemene geheugenverbetering is niet mogelijk met een dergelijke aanpak. Inmiddels zijn er echter serieuze onderzoeken verschenen die laten zien dat dergelijke hersengymnastiek wél positieve effecten heeft op het dagelijks geheugen. Bescheiden effecten, maar toch. Vooral werkgeheugentrainingen lijken effectief. Het werkgeheugen kunt $u$ beschouwen als de cognitieve werkbank van het denken en handelen. En, naar analogie van de werkbank in de schuur, bepaalt de grootte van het werkgeheugen mede het aantal cognitieve taken dat $u$ tegelijkertijd kunt doen. Het is zeer de moeite waard om de meerwaarde van deze cognitieve trainingen goed te onderzoeken - mogelijk hebben we ons vergist en blijken onze hersenen meer plastisch en trainbaar dan we altijd hebben aangenomen.

Samen met onder anderen collega Caroline van Heugten wil ik mij richten op de late emotionele en gedragsmatige gevolgen van hersenletsel. Denk bijvoorbeeld aan apathie, agressie, depressie en persoonlijkheidsveranderingen. Dat willen we mede vorm geven door een specialistische neuropsychologische behandelpoli in te richten. Voor deze poli wordt samenwerking gezocht met het revalidatiecentrum Adelante en de afdeling Neurologie van het AZM. Klinische zorg zal gecombineerd worden met wetenschappelijk onderzoek. Een van de belangrijke onderzoeksvragen daarbij is of al vroeg na het hersenletsel risicofactoren of voorspellers kunnen worden geïdentificeerd die een verhoogd risico vormen voor het optreden van deze late gevolgen. Deze risicofactoren zullen deels direct patiëntgebonden zijn, zoals een 
verminderd ziekte-inzicht of rigiditeit, maar deels ook gelegen zijn in de omgeving van de patiënt, zoals een beperkt sociaal netwerk of een partner die niet de juiste bejegening geeft. Tevens is dit de plek waar we neuropsychotherapie verder willen ontwikkelen en evalueren en specifiek ook aandacht hebben voor de al genoemde cogniforme stoornissen. Ook is er aandacht voor het onderzoek naar de 'ABCmethode' voor probleemgedrag bij hersenletsel patiënten. De ABC-methode is een sterk vereenvoudigde vorm van gedragsanalyse vanuit een leertheoretisch kader, speciaal ontwikkeld voor verpleging en verzorging. Het biedt een kader om gedragsproblemen in termen van oorzaak en gevolg te begrijpen en bij te sturen. Momenteel wordt deze methode geïntroduceerd en geëvalueerd bij diverse zorginstellingen in het land. We willen tevens onderzoeken of en in hoeverre de $A B C$-methode geschikt kan worden gemaakt voor de familie van thuis verblijvende hersenletselpatiënten.

Een laatste onderzoeksthema betreft de kwaliteit van psychodiagnostische onderzoeken in relatie tot de inzet en motivatie van patiënten. Patiënten presteren bij testonderzoek niet altijd optimaal, waardoor prestaties te laag uitvallen. Ook kunnen patiënten buitenproportioneel veel klachten weergeven in het klinische interview of op vragenlijsten. Deze problemen kunnen zich voordoen bij alle patiënten waarbij psychodiagnostiek wordt verricht, niet alleen dementie- of hersenletselpatiënten. De redenen van onderpresteren of overrapporteren zijn divers: men wil bijvoorbeeld benadrukken hoe ziek men is, men is te moe, gedemotiveerd of angstig. In het slechtste geval simuleert de patiënt om daarmee een voordeel te halen, zoals een uitkering. In alle gevallen is er sprake van een onbetrouwbaar en invalide diagnostisch onderzoek dat leidt tot foute diagnoses of behandelingen. Met alleen het klinisch oog zijn onderpresteren en overrapporteren niet gemakkelijk vast te stellen, al menen veel psychologen ten onrechte van wel. Het promotieonderzoek van Brechje Dandachi-FitzGerald richt zich op de kwaliteit van specifieke tests en vragenlijsten gericht op het detecteren van onderpresteren en overrapporteren. Dit onderzoek zal uitmonden in richtlijnen voor de klinische praktijk. lets waar al lang naar wordt uitgekeken.

\section{Dankwoord}

Dames en heren, Ik zou u graag meer willen vertellen over mijn prachtige vak, maar een oratie is nu eenmaal gelimiteerd op drie kwartier. Ook gelimiteerd is het dankwoord. Een ellenlange opsomming van namen en instellingen wordt dringend afgeraden. Dat is ook het beste, maar het brengt mij ook in een ongemakkelijke positie. Het feit dat ik deze mooie benoeming heb gekregen, is toch vooral het resultaat van de samenwerking met veel collega's op veel verschillende 
werkplekken. Ik kan zeker niet iedereen memoreren. Daarom, voor wie ik niet noem - een welgemeend dank.

Ik dank het college van bestuur van de universiteit Maastricht en de raad van bestuur van het academisch ziekenhuis voor het vertrouwen dat ze in mij uitspreken met deze benoeming. Daarmee wordt ook het belang onderstreept dat de afdeling medische psychologie weer herkenbaar aanwezig moet zijn binnen het academisch ziekenhuis en het MUMC.

Voor mijn academische en klinische vorming zijn twee personen van bijzonder belang geweest: prof. Betto Deelman, de geduldige, en prof Jelle Jolles, de daadkrachtige. Hun verschillende kijk op het vak van de neuropsychologie én hun contrasterende werkstijlen bleken voor mij zeer leerzaam.

Jim van Os was de drijvende kracht achter mijn benoeming. Enkele jaren geleden haalde je me terug naar het ziekenhuis. Niet lang daarna meldde je terloops dat het ook wenselijk was dat ik afdelingshoofd en hoogleraar zou worden. Met jouw indrukwekkende carrière is zoiets 'klein bier', maar voor mij was het nogal een mentale stap. Gelukkig duurde de benoemingsprocedure ook weer zó lang, dat ik er rustig aan kon wennen.

Frans Verhey is 'de dokter' met wie ik nu al meer dan 23 jaar samenwerk. In mijn proefschrift noemde ik je een even enthousiast als kritisch grootgebruiker van de neuropsychologie. Daarin is weinig veranderd. Mijn kritische beschouwingen over hoe psychologen hun vak verkopen is mede geënt op jouw expliciete en impliciete commentaar op ons werk. Ga zo door, het houdt ons scherp.

Met Caroline van Heugten werk ik al vele jaren op zeer plezierige wijze samen. We delen de passie voor de neuropsychologie en blijken een goed koppel. Jouw wetenschappelijke gedegenheid en mijn klinische ervaring gaan mooie dingen opleveren. Zoveel is zeker.

Deze oratie draag ik op aan drie personen. Aan wijlen mijn ouders die oprecht verbaasd zouden zijn nu 'de twee kleintjes' uit het grote nest, héle grote leraren zijn geworden. 'Da-hei mooi doane jongs', zou mijn vader vandaag hebben gezegd. Achterhoekers zijn kort van stof bij complimenten, maar menen het des te meer. Aan wijlen Peter Houx, door mij zeer gewaardeerd als collega en mens en met wie ik deze mijlpaal in mijn carrière graag had gedeeld. Met wie ik bovendien voor altijd verbonden ben in het vermaledijde woord 'zeekomkommer'. Ik laat het bij deze cryptische opmerking, maar u zult vast navraag doen. 
Phil, Stef, Thomas en Renate, jullie zijn allemaal uitgevlogen en het is prachtig te zien hoe jullie het eigen pad kiezen, vaak letterlijk heel ver weg. Het gaat goed met jullie, dat geeft ons niet alleen heel veel plezier, maar ook rust en zekerheid.

Mijn Ingrid, zo klein als ze is, zo groot is haar steun die ze gevraagd en ongevraagd biedt. Wij delen de lusten en lasten van mooie en zelfs aanvullende banen en relativeren elkaars zorgen. Naast hard werken, kunnen we samen heel goed ontspannen en dat is een groot goed. Het is even enerverend als fantastisch om jou als mijn vrouw te hebben.

Ik heb gezegd 


\section{Referenties}

1 Kaptein AA, Prins JB, Colette EH, Hulsman RL. Medisch psychologie in context. In: Kaptein AA, Prins JB, Colette EH, Hulsman RL: Medische Psychologie. Houten: Bohn, Stafleu \& van Loghum, 2010.

2 Beroepscode voor psychologen (Nederlands Instituut van Psychologen). Amsterdam: NIP, 2007.

3 Algemene Standaard Testgebruik - AST (Nederlands Instituut van Psychologen). Amsterdam: NIP, 2010.

4 Kooreman A. Het psychologisch rapport - van sluitpost tot visitekaartje. Amsterdam: Pearson, 2006.

5 Kamphuis JH. Therapeutische psychodiagnostiek (inaugurele rede). Amsterdam (UvA), 26 november 2010.

6 Van der Molen HT. De mededeelzame detective. Pleidooi voor een transparante toegepaste psychologie (inaugurele rede). Heerlen (OU), 24 juni 1994.

7 Van der Staak CPF. De klinisch psycholoog als scientist-practitioner. In Soons PHGM, Albrecht R: De klinisch psycholoog in het algemene ziekenhuis (deel 10, uitgave sectie PAZ, NIP). Twello: Robine, 2005.

8 Kaptein AA, Beunderman R, Dekker J, Vingerhoets AJJM. Psychologie en geneeskunde (Behavioral Medicine). Houten: Bohn, Stafleu \& van Loghum, 2006.

9 Soons PHGM. Psychologen in de somatische gezondheidszorg. In: Kaptein AA, Beunderman R, Dekker J, Vingerhoets AJJM. Psychologie en geneeskunde (Behavioral Medicine). Houten: Bohn, Stafleu \& van Loghum, 2006.

10 Verhey FRJ, Ponds RWHM, Jolles J, van der Lugt PJM. Een nieuw psychogeriatrisch syndroom: de vergeetfobie. Medisch Contact 1991, 575-576.

11 Ponds RWHM, Steins E. Een geheugen van twee dagen. Tijdschrift voor Neuropsychologie 2007, 32-40.

12 Delis DC, Wetter SR. Cogniform disorder and cogniform condition: proposed diagnoses for excessive cognitive symptoms. Archives of Clinical Neuropsychology 2007, 589-604.

13 De Wit P, Derix M. Somatische neuropsychologie. In: Hendriks $M$, Kessels R, Gorissen $M$, Schmand B. Neuropsychologische diagnostiek - de klinische praktijk. Amsterdam: Boom, 2006.

14 Verhey FRJ. Oud en vergeten, de lessen van Alzheimer (inaugurele rede). Maastricht (UM), 11 oktober 2002.

15 Myin-Germeys I, et al. Experience sampling research in psychopathology; opening the black box of daily life. Psychological Medicine 2009, 1533-1547. 